\title{
The Quality of Local Government Reports in Indonesia: A Meta Analysis Study
}

\author{
Dewa Made Adi Dharma ${ }^{1}$, Muhammad Din ${ }^{2 *}$, Fikry Karim, Masruddin ${ }^{3}$ \\ ${ }^{1,2,3}$ Faculty of Economics and Business, Tadulako University, Indonesia \\ Correspondent Email: didi.kaili83@gmail.com
}

\begin{abstract}
This research aims to describe the data measuring variables with respect to the quality of government financial reports. This is a descriptive statistical research that uses a meta-analysis method in analyzing the data. The collection of data involved the use of documentation techniques drawn from previous research journal papers related to the quality of government financial reports. This study found that among 45 data measuring variables, there were 34 variable that have a significant effect and 11 variables with no significant effect.
\end{abstract}

Keywords: Meta-Analysis, Quality of Local Government Financial Statements, Statistic Descriptive, Indonesia

\section{INTRODUCTION}

Based on previous public sector accounting research literature, there is still disagreement about the usefulness of government financial reporting, whether it has developed into a decision-making tool or is still limited to fulfilling responsibilities (laws and regulations) in achieving accountability. Steccoloni (2004), Ryan and Mack (2006), Groot and Budding (2008) According to the findings of their research in Italy, Australia, and the Netherlands, government financial reporting, including the use of accrual-based accounting schemes, is still focused on meeting regulatory requirements and achieving transparency, thus having minimal capacity to act as a decisionmaking tool.

Meanwhile, based on the results of research Alijarde (2002) found that Local Government Financial Reports were found to be used in decision making for finance directors, government management, and other potential users such as auditors, financial entities, and other stakeholders, with one of them being used to assess the extent to which financial accountability and compliance with budget execution. As research from Muraina and Dandago (2019) has conducted research in which the research objective is to examine and analyze the effect of IPSAS implementation on the quality of the Nigerian government's financial statements. The findings of this research are accountability which is an indicator of the IPSAS variable that has a positive and significant effect on the quality of Nigeria's financial statements. This shows that IPSAS has increased the level of accountability which also has implications for the quality of Nigeria's financial reports. In addition to the contradictions about the usefulness of the quality of local government financial reports, until now there are also many other factors that affect the financial statements of local governments.

Research from Nkundabanyanga et al., (2013) in Uganda found that Accounting Standards and Legal Frameworks have a positive and significant impact on the Quality of Financial Statements in the Ugandan Ministry of Government. In line with this, Makhaiel (2016) in Egypt, namely Egypt's political-economic reforms have a negative effect on the quality of the Egyptian government's financial reports. Politicaleconomic reforms led to privatization that had the following impacts: Deviation from a uniform accounting system and regulations on public accountants, issuing new regulations on stock exchanges, reviving the role of stock exchanges, and increasing competition in stock exchanges. Furthermore, Benito et al., (2003) discussed the comparison of the quality of financial reports of local and central governments in Spain. The findings are that local governments in Spain have developed good financial reporting standards, an accounting system that is still underdeveloped and informative with an accounting information system that has been adopted by the central government. 
According to Hariadi (2010) defines the quality of financial statements as normative benchmarks embodied in accounting information so that it can meet its objectives. In order for regional financial reports to meet quality, financial statements must also meet the qualitative characteristics of financial statements, namely relevant, reliable, comparable, and understandableTo meet the benchmarks in presenting quality financial reports, the government has issued regulations that regulate and manage the presentation of financial statements. The regulation is PP No. 71 of 2010 concerning Government Accounting Standards which is one of the conceptual frameworks that underlies the preparation and presentation of government financial statements. The goal is to serve as a reference for government financial statement preparers in carrying out their duties.

he quality of government financial reports can be investigated by conducting an analytical mapping. According to Glass et al., (1981) Meta analysis is a quantitative analysis that utilizes large amounts of data and uses statistical techniques to organize various data from large samples for the purpose of complementing other purposes. The research conducted by the researcher this time aims to analyze how influential the measurement variables regarding the quality of government financial reports in Indonesia are obtained from the results of previous research journals regarding the quality of local government financial reports as the dependent variable.

\section{LITERATURE REVIEW}

\subsection{Public Sector Accounting}

According to Bastian (2010) it is a technical framework and accounting study that is applied to the management of public funds in high state institutions and ministries under them, local governments, BUMN, BUMD, NGOs, and social foundations.

In line with Bastian's statement. according to Mardiasmo (2003) defines accounting in the public sector as functioning as a monitoring and information mechanism for the government and the general public. In line with Mardiasmo, Halim (2002) tates the notion of accounting in the public sector as a service operation that involves the provision of quantitative data, especially financial ones. , from government agencies so that interested parties can make sound economic decisions about alternative courses of action. According to Bastian (2010) the elements of public sector accounting are the parts needed in the management of public financial management. Public sector accounting consists of the following elements: Public Planning, Public Budgeting, Budget Realization, Public Procurement of Goods and Services, Public Sector Financial Reporting, Public Sector Audit, Public Accountability,

\subsection{Quality of Government Financial Reports}

According to Bastian (2006) the financial status of transactions carried out by public sector organizations is reflected in public sector financial statements. In line with Bastian, Yadiati and Mubarok (2017) explain financial reporting is the process of disclosing financial details to meet user needs while protecting the interests of owners. It focuses on the qualitative characteristics of financial data as well as full and fair disclosure.

\section{METHOD}

The research method used is descriptive statistical analysis. Hasan (2001) explains that descriptive statistics or deductive statistics are part of statistics, studying how to collect data and present data so that they are easy to understand. Descriptive statistics are only interested in explaining or providing information about a set of data, situations, or phenomena. The term descriptive statistics refers to the process of describing a state, symptom, or problem.

This paper describes the independent variables that have a significant effect as a measure of the quality of government financial reports using the meta-analysis method. As for the statistics in this study using the mode method, which is used to collect the most data in the measurement variables. The type of data used in this study is secondary data, namely data obtained from other parties in the form of data in the form of publications. The source of data in this study is in the form of previous research journals about the quality of government financial reports obtained through documentation techniques. The collection of previous research studies on the quality of the latest government financial reports, namely the documentation technique that has been carried out in this paper.

Table 1 Variables as research data

\begin{tabular}{|c|l|c|}
\hline $\begin{array}{c}\text { No } \\
\cdot\end{array}$ & \multicolumn{1}{|c|}{ Variabel Independen yang digunakan } & Tahun \\
\hline 1 & $\begin{array}{l}\text { Election Year } \\
\text { (Agustina and Setyaningrum, 2020) }\end{array}$ & 2020 \\
\hline 2 & $\begin{array}{l}\text { Application of the Regional Financial Accounting System } \\
\text { Putri and Agustiawan (2020) }\end{array}$ & 2020 \\
\hline 3 & $\begin{array}{l}\text { Compliance with Laws and Regulations } \\
\text { Mawuntu et al., (2020) }\end{array}$ & 2020 \\
\hline
\end{tabular}




\begin{tabular}{|c|c|c|}
\hline 4 & $\begin{array}{l}\text { Application of Regional Financial Information System } \\
\text { Yenni et al., (2020) }\end{array}$ & 2020 \\
\hline 5 & $\begin{array}{l}\text { Utilization of Information Technology } \\
\text { Putri and Agustiawan (2020) }\end{array}$ & 2020 \\
\hline 6 & $\begin{array}{l}\text { Information and Communication } \\
\text { Triono and Dewi (2020) }\end{array}$ & 2020 \\
\hline 7 & $\begin{array}{l}\text { Supervision } \\
\text { Mawuntu et al. (2020) }\end{array}$ & 2020 \\
\hline 8 & $\begin{array}{l}\text { Implementation of Regional Management Information } \\
\text { System } \\
\text { Azzindani and Irwan (2020) }\end{array}$ & 2020 \\
\hline 9 & $\begin{array}{l}\text { Risk Assessment } \\
\text { Triono and Dewi (2020) }\end{array}$ & 2020 \\
\hline 10 & $\begin{array}{l}\text { Follow-up Audit Recommendations } \\
\text { (Agustina and Setyaningrum, 2020) }\end{array}$ & 2020 \\
\hline 11 & $\begin{array}{l}\text { Implementation of Government Accounting System } \\
\text { Putri and Agustiawan (2020) }\end{array}$ & 2020 \\
\hline 12 & $\begin{array}{l}\text { Monitoring } \\
\text { Triono and Dewi (2020) }\end{array}$ & 2020 \\
\hline 13 & $\begin{array}{l}\text { HR Competence } \\
\text { (Handayani et al.,, 2020) }\end{array}$ & 2020 \\
\hline 14 & $\begin{array}{l}\text { Apparatus Performance } \\
\text { Azzindani and Irwan (2020) }\end{array}$ & 2020 \\
\hline 15 & $\begin{array}{l}\text { Good Government Governance } \\
\text { Azzindani and Irwan (2020) }\end{array}$ & 2020 \\
\hline 16 & $\begin{array}{l}\text { Internal Audit Roles and Functions } \\
\text { (Handayani } \text { et al., 2020) }\end{array}$ & 2020 \\
\hline 17 & $\begin{array}{l}\text { Control Environment } \\
\text { Triono and Dewi (2020) }\end{array}$ & 2020 \\
\hline 18 & $\begin{array}{l}\text { Financial Accountability } \\
\text { Idawati and Eleonora (2019) }\end{array}$ & 2020 \\
\hline 19 & $\begin{array}{l}\text { Control Activities } \\
\text { Triono and Dewi (2020) }\end{array}$ & 2020 \\
\hline 20 & $\begin{array}{l}\text { Political Competition } \\
\text { (Agustina and Setyaningrum, 2020) }\end{array}$ & 2020 \\
\hline 21 & $\begin{array}{l}\text { Accounting Understanding } \\
\text { Yenni } \text { et al. }(2020)\end{array}$ & 2020 \\
\hline 22 & $\begin{array}{l}\text { Principles of Regional Financial Management } \\
\text { (Indriani, 2019) }\end{array}$ & 2019 \\
\hline 23 & $\begin{array}{l}\text { Government Internal Control System } \\
\text { (Febri et al.,, 2019) }\end{array}$ & 2019 \\
\hline 24 & $\begin{array}{l}\text { Regional Property Management } \\
\text { (Eriadi et al.,, 2018) }\end{array}$ & 2019 \\
\hline 25 & $\begin{array}{l}\text { Review of Financial Statements } \\
\text { (Baturante } \text { et al.,, 2018) }\end{array}$ & 2018 \\
\hline 26 & $\begin{array}{l}\text { Proof of Ownership of Fixed Assets } \\
\text { (Eriadi } \text { et al., 2018) }\end{array}$ & 2018 \\
\hline 27 & $\begin{array}{l}\text { Work experience } \\
\text { (Budiono } \text { et al.,, 2018) }\end{array}$ & 2018 \\
\hline 28 & $\begin{array}{l}\text { Organizational Commitment } \\
\text { (Agung and Gayatri, 2018) }\end{array}$ & 2018 \\
\hline 29 & $\begin{array}{l}\text { Behavioral Motivation } \\
\text { (Eriadi } \text { et al., 2018) }\end{array}$ & 2018 \\
\hline 30 & $\begin{array}{l}\text { Bureaucratic Culture } \\
\text { (Baturante } \text { et al., 2018) }\end{array}$ & 2018 \\
\hline 31 & $\begin{array}{l}\text { Fixed Asset Valuation } \\
\text { (Eriadi } \text { et al., 2018) }\end{array}$ & 2018 \\
\hline 32 & $\begin{array}{l}\text { Accountability } \\
\text { (Febri } \text { et al., 2019) }\end{array}$ & 2018 \\
\hline 33 & $\begin{array}{l}\text { Education and Training } \\
\text { (Budiono } \text { et al., 2018) }\end{array}$ & 2018 \\
\hline 34 & $\begin{array}{l}\text { Leadership Style } \\
\text { (Agung and Gayatri, 2018) }\end{array}$ & 2018 \\
\hline 35 & $\begin{array}{l}\text { Review Process } \\
\text { (Juanda and Nauli, 2018) }\end{array}$ & 2018 \\
\hline 36 & $\begin{array}{l}\text { Professionalism } \\
\text { (Basar, 2017) }\end{array}$ & 2017 \\
\hline 37 & $\begin{array}{l}\text { Follow-up on improvements to the Weaknesses of } \\
\text { Accounting and Reporting Implementation } \\
\text { (Djanegara, 2017) }\end{array}$ & 2017 \\
\hline 38 & $\begin{array}{l}\text { Financial Administration Officer Accounting Competence } \\
\text { (Lubis and Saripudin, 2017) }\end{array}$ & 2017 \\
\hline 39 & $\begin{array}{l}\text { Follow-up Improvements for Non-compliance with Laws } \\
\text { and Regulations } \\
\text { (Djanegara, 2017) }\end{array}$ & 2017 \\
\hline
\end{tabular}

\begin{tabular}{|c|l|c|}
\hline 40 & $\begin{array}{l}\text { Transfer of Financial Administration Officer } \\
\text { (Lubis and Saripudin, 2017) }\end{array}$ & 2017 \\
\hline 41 & $\begin{array}{l}\text { Knowledge of Inspectorate Apparatus } \\
\text { (Basar, 2017) }\end{array}$ & 2017 \\
\hline 42 & $\begin{array}{l}\text { Follow-up on Weaknesses in Accounting and Reporting } \\
\text { Systems } \\
\text { (Djanegara, 2017) }\end{array}$ & 2017 \\
\hline 43 & $\begin{array}{l}\text { Leadership Commitment } \\
\text { (Lubis and Saripudin, 2017) }\end{array}$ & 2017 \\
\hline 44 & $\begin{array}{l}\text { Follow-up Improvements on Weaknesses in the Internal } \\
\text { Control structure } \\
\text { (Djanegara, 2017) }\end{array}$ & $\begin{array}{l}\text { Commitment of Financial Administration Officer } \\
\text { (Lubis and Saripudin, 2017) }\end{array}$ \\
\hline
\end{tabular}

\section{RESULTS AND DISCUSSION \\ 4.1. Data Analysis}

Researchers conducted a mapping of the measurement variables used in the quality of government financial reports in Indonesia, the latest in the last three years. The mapping carried out by the researcher will produce a description of the research results of each mapped variable which has a significant effect on the quality of local government financial reports.

\subsection{Discussion}

It can be seen from the data analysis that has been carried out by researchers from 50 variables from various journals which are the measurement variables for the quality of government financial reports. Starting from the variable of Accounting Understanding. The variable of accounting understanding has a significant positive effect on the quality of financial statements. Understanding of Accounting in this study is proven to be able to provide a significant contribution in influencing the Quality of OPD financial statements. This condition shows that the level of Accounting Understanding increases, the Quality of Local Government financial reports also tends to increase as well. Furthermore, the Regional Financial Information System has a significant influence, which means that if the implementation of SIKD is good, it will be able to produce higher quality financial reports

Followed by the application of SAP, the significant positive effect shows that the better the implementation of government accounting standards, the better the quality of local government financial reports. Government Accounting Standards are guidelines for the presentation of financial statements. Local governments have an obligation to present financial reports as a form of responsibility for financial management. The financial statements made must 
contain elements that have been regulated in government accounting standards.

Furthermore, research on the Regional Financial Accounting System has significant results. so that the better the regional financial accounting system, the better the quality of the financial reports, with the implementation of the regional financial accounting system it can facilitate a series of procedures starting from the process of data collection, recording, summarizing, to financial reporting in the context of accountability for the implementation of the APBD which can be done manually or using computer applications. The regional financial accounting system functions to provide quantitative information, especially financial in nature, about economic entities that is intended to be useful in making economic decisions and to increase the accountability and reliability of government financial management.

In line with this, the variable of compliance with laws and regulations finds influential results. This ensures that the more laws local governments comply with, the higher the standard of financial reporting they produce. This shows that local governments are sensitive to related regulations. Not aligned with compliance, the internal control variable has no influence on the quality of local government financial reports. This is allegedly due to the lack of experienced officials in the field of accounting as preparers and presenters of financial statements, as well as the absence of external audits or reliable standards.

On the other hand, the Human Resource Competence variable significantly influences the quality of local government financial reports. An HR competency is needed to produce a good quality financial report composition. Human resources who have accounting skills and expertise will make it easier for employees to prepare financial reports. Internal Control has five indicators which are described as follows: The control environment has a significant influence. This implies that the control environment must be changed and simplified, which can be achieved by establishing an organizational framework that is in line with the requirements. The two components of the regional apparatus have been integrated (unified). Integrity and ethical principles are very well maintained. Develop a leadership environment conducive to success. Interact with officials on a regular basis. Implement performance-based management.
Meanwhile, Risk Assessment also has a significant influence on the quality of local government financial reports. This means that risk evaluation needs to be strengthened and streamlined. This can be achieved by ensuring that: the identification and analysis of risks is carried out properly; includes statements and directions that are precise, observable, attainable, reasonable, and time bound. All employees are informed. Government agencies have used appropriate tools to classify threats from external and internal influences based on their objectives and strategic plans.

Not in line with risk assessment, control activities do not have a significant effect. This ensures that control activities do not affect local government financial statements, so that control activities can be further improved. On the other hand, knowledge and communication affect the quality of LKPD. This ensures that information and communication must be improved and simplified. This can be achieved by the leader identifying, recording, and communicating information in an appropriate form and at the right time.

As with communication information, monitoring also has an effect. Ensure that the quality of financial reports must be optimized, which can be achieved by presenting information about whether or not the techniques used are correct. Evaluate activities by looking for opportunities for more acceptable, practical, successful and productive strategies, services and activities. In line with monitoring, SIMDA implementation also affects the quality of LKPD. This indicates that the higher the SIMDA implementation, the higher the quality of the financial reports produced by the local government. In line with SIMDA implementation, Apparatus Performance variable also has an influence but not significantly on the quality of LKPD. The related argumentative reasons are not significant because of overlapping laws and regulations so that often the apparatus does not have time to understand the old rules and new rules are issued regarding the preparation of LKPD.

There is Good Government Governance has a significant influence. This shows that the type of transparency of information provided in LAKIP is quite strong, shown by the performance of the transparency mechanism in the delivery of information released by local governments, justice in law enforcement or punishments imposed on employees who violate the 
rules are sufficient, as well as the willingness of local governments to assess responsiveness to community needs and equity in the placement of qualified workers.

Follow-up recommendations affect the quality of the LKPD. This condition also strengthens several theories that support the assumption that by following up on recommendations the local government seeks to gain legitimacy from the community through the provision of useful information in financial reports. These results also indicate that BPK has a role in assisting local governments in improving the quality of financial reports through appropriate and easy-to-follow recommendations. Political competition shows an insignificant effect, this is because political competition increases the disclosures made in financial statements but does not improve the quality of the information disclosed. This also indicates that the DPRD as a supervisory body only ensures whether or not there is disclosure of information in the financial statements, without paying attention to the quality of the information. The DPRD's capacity is still low to understand the importance of high-quality financial reports.

In addition, the election year has a significant relationship to the quality of the LKPD. Based on the legitimacy theory, DPRD as a supervisory body acts according to social norms to gain legitimacy from the people who have delegated authority through legislative elections. In an election year, the DPRD as a supervisory body showed strong control to ensure proper governance to signal to the public that they were doing well. The DPRD wants to provide evidence of political promises made to the public in campaigns and encourage local governments to compile quality financial reports.

Employee loyalty to the company is proportional to the dedication of the employee's organization. Employee performance morale and internal monitoring are expected to increase as a result of a high level of loyalty. Organizational Commitment Variable has an effect on LKPD Quality. Another variable, namely the role and function of the internal audit, has a significant influence on the quality of the LKPD. This can be interpreted that the better the involvement of internal control over the preparation of financial statements will improve the quality of financial reports. The fairness of the reported financial statements is influenced by an efficient internal audit function that involves preparation, communication, and approval, resource management, policies and procedures, scheduling, reporting to management, program implementation and quality control, as well as follow-up on public concerns.

However, on the other hand, the Financial Statement Review variable reported that internal audit did not do it explicitly in the preparation of the LKPD and had no relationship. This condition is inversely proportional to the review process variable which has a significant positive effect on the quality of local government financial reports. It can be interpreted that the better the review process on the Regional Government Financial Reports can improve the quality of the Regional Government Financial Reports. HR competence has a significant influence on the quality of LKPD. The quality of financial reports will definitely improve as a result of professional human resources in the financial management of local government work units. A significant effect is shown on the financial accountability variable. This shows that local government financial reports are handled in an orderly manner, in accordance with statutory regulations, and are reliable, efficient, economical, open, and accountable while still taking into account the principles of justice, propriety, and society. benefits.

Similar to accountability, the principles of regional financial management also have a significant influence. This means that the level of application of financial management principles including accountability, time value of money, honesty in managing public finances, transparency and high control will improve the quality of local government financial reports. The Government's Internal Control System has positive results and this condition explains that the better the implementation of SPIP, the better the accountability of the organization.

This is not in line with the Bureaucratic Culture which has no influence. The bureaucratic culture is only determined by compliance, not performance. Although some compliance practices may limit the efficiency of an organization, good compliance practices will still help the organization's activities to be efficient and successful. This research further shows the results that leadership style has a positive effect on the quality of local government financial reports. A person's leadership style can affect the attitudes and behavior of members of the organization, as well as their success in 
carrying out their duties and responsibilities. In line with that, behavioral motivation variables, evidence of ownership of regional property, routine assessment of fixed assets, and management of regional property are significantly influential on the quality of LKPD. This condition must be met in order for the management of regional assets to run effectively and efficiently, so that regional asset managers must adhere to the principles of.

Education and training have no significant effect on the quality of local government financial reports. This is because not all workers with a high level of education understand and can solve problems in local financial reports, and the institutional system does not always improve poor performance. In line with education, the variable of Work Experience, This is because not all workers complete the work that is their duty on time and free from errors. The professionalism of the inspectorate apparatus has a significant positive effect on the quality of the LKPD. This situation is interpreted by the professionalism of the local government inspectorate apparatus which plays an important role in the implementation of the review and development of each SKPD, which has a direct impact on the quality of the LKPD.

In line with Professionalism, Knowledge of Inspectorate Apparatus has a significant influence on the quality of LKPD. It can be proven that the inspectorate apparatus has a strong understanding of regional financial management knowledge. However, inspectorate officers must develop their competence and expertise to be attentive in detecting anomalies and findings during the audit process in each SKPD. The inspectorate apparatus will easily determine what must be done to overcome these problems by tracing the preparation of the budget to the realization of the budget in each government agency.

Furthermore, there are variables, namely Accounting Competence, Official Commitment, Official Transfer, and Financial Administration Leadership Commitment that have no influence on the quality of LKPD. There are suggestions regarding the ineffectiveness of all these variables, namely the placement and appointment of financial administration officials (PPK) prioritizing officials who have accounting education experience, accounting competency credentials, and high dedication to organizational goals so that local governments can increase leadership commitment. Similarly, when making worker transitions, use the concept of "right person, right position" to achieve organizational goals, such as getting a WTP opinion.

Then the Audit Quality variable describes the four indicators used to test the hypothesis, namely follow-up improvements to the weaknesses of the accounting and reporting systems, follow-up improvements to budget implementation weaknesses, follow-up improvements to internal control structure weaknesses, and follow-up improvements to noncompliance with laws and regulations. All indicators have a significant influence on the quality of the LKPD. As a supply chain in increasing transparency and accountability of state financial management, this situation refers to the consistency of auditing financial statements.

\section{CONCLUSIONS}

Based on the explanation of the results and discussion in this study, it was found that among 45 data variables measuring the quality of local government financial reports, there were 34 data variables that had a significant effect and 11 data variables that did not have a significant effect. It is hoped that further research will conduct a meta-analysis of the history or state of the art as well as the measurements used in research on the quality of local government financial reports.

\section{REFERENCES}

Agung, T. M., and Gayatri. 2018. "Analisis FaktorFaktor yang Mempengaruhi Kualitas Laporan Keuangan Pemerintah Daerah Kabupaten Karangasem". E-Jurnal Akuntansi Universitas Udayana, Vol. 23, No. 2, hlm: 1253-1276.

Agustina, N., and D. Setyaningrum. 2020. "Determinants Quality of Local GovernmentFinancial Statements in Indonesia". Review of Integrative Business \& Economics Resarch, Vol. 9, No. 3, hlm: 226239.

Alijarde, M. I. B. 2002. "The Usefulness of Financial Reporting in Spanish Local Governments". Financial Accountability \& Management, Vol. 13, No. 1, hlm: 17-34.

Azzindani, R., and M. Irwan. 2020. "Pengaruh Implementasi SIMDA dan Kinerja Aparatur Pemerintah Daerah Terhadap Kualitas Laporan Keuangan Dimediasi Good Government Governance". Jurnal Studi Akuntansi dan Keuangan, Vol. 3, No. 1, hlm: 31-54.

Basar, N. 2017. "Pengaruh Profesiionalisme dan Pengetahuan Aparat Inspektorat Terhadap 
Kualitas Laporan Keuangan Pemerintah Daerah". Jurnal Economix, Vol. 5, No. 1, hlm: 226-237.

Bastian, I. 2006. Akuntansi Sektor Publik: Suatu Pengantar. Jakarta: Erlangga.

2010. Akuntansi Sektor Publik. Jakarta: Salemba Empat.

Baturante, N., J. Kamase, and F. Nasarudin. 2018. "Faktor-Faktor Yang Mempengaruhi Kualitas Laporan Keuangan Pemerintah Daerah Provinsi Sulawesi Selatan". Journal of Management \& Business, Vol. 1, No. 2, hlm: 117-127.

Benito, B., V. Montesinos, and J. M. Vela. 2003. "Local and Regional Accounting and Reporting in Spain: An Empirical Outlook". Journal of Public Budgeting, Accountig \& Financial Management, Vol. 15, No. 1, hlm: 67-91.

Budiono, V. S., Muchlis, and I. Masri. 2018. "Analisis Pengaruh Pendidikan dan Pelatihan, Pengalaman Kerja, Serta Pemanfaatan Teknologi Informasi Terhadap Kualitas Laporan Keuangan Pemerintah Daerah.". Jurnal Ilmiah Wahana Akuntansi, Vol. 13, No. 2, hlm: 110-128.

Djanegara, M. S. 2017. "Pengaruh Kualitas Audit Terhadap Kualitas Laporan Keuangan Pemerintah Daerah". Jurnal Akuntansi, Vol. 21, No. 3, hlm: 461-483.

Eriadi, Erlina, I. Muda, and S. Abdullah. 2018. "Determinant Analysis Of The Quality Of Local Government Financial Statements in North Sumatra With The Effectiveness Of Management Of Regonal Property as A Mediator". International Journal of Civil Engineering nd Technology, Vol. 9, No. 5, hlm: 1334-1346.

Febri, D., S. Rahayu, and Wiralestari. 2019. "Pengaruh Penerapan SAP, Kompetensi SDM, SPIP Terhadap Kualitas Laporan Keuangan Pemerintah Daerah dengan Akuntabilitas Sebagai Variabel Intervening (Studi Empiris di Kota Jambi)". Jurnal Akuntansi \& Keuangan UNJA, Vol. 4, No. 3, hlm: 38-52.

Glass, G. V., B. McGaw, and M. L. Smith. 1981. MetaAnalysis in Social Research. Beverly Hills: Sage Publication.

Groot, T., and G. T. Budding. 2008. "New Public Management's Current Issues and Future Prospects". Financial Accountability \& Management, Vol. 24, No. 1, hlm: 1-13.

Halim, A. 2002. Akuntansi Keuangan Daerah. Jakarta: Salemba Empat.
Handayani, F., Erlina, and E. S. RIni. 2020. "Factors That Affect The Quality of The Governments Financial Statements in Medan". International Journal of Public Budgeting Accounting and Finance, Vol. 3, No. 1, hlm: 139-152.

Hariadi, P. 2010. Pengelolaan Keuangan Daerah. Jakarta: Salemba Empat.

Hasan, I. 2001. Pokok-Pokok Materi Statistik 1 (Statistik Deskriptif). Jakarta: PT Bumi Aksara.

Idawati, W., and L. Eleonora. 2019. "Penerapan Sstem Pengendalian Intern dan Akuntabilitas Keuangan dalam Mewujudkan Kualitas Laporan Keuangan". Equity, Vol. 22, No. 2, hlm: 153-172.

Indriani, M. R. 2019. "Faktor-Faktor Yang Mempengaruhi Kualitas Laporan Keuangan Pemerintah Daerah". Jurnal Ilmu dan Riset Akuntansi, Vol. 8, No. 1, hlm: 1-15.

Juanda, A., and Nauli. 2018. "Pengaruh Proses Reviu Terhadap Kualtas Laporan Keuangan Pemerintah Daerah". Jurnal Akuntansi \& Keuangan (JAK), Vol. 23, No. 1, hlm: 41-54.

Lubis, I., and Saripudin. 2017. "Pengaruh Kompetensi Akuntansi, Komitmen, dan Mutasi Terhadap Kualitas Laporan Keuangan Pemerintah Daerah: Komitmen Pimpinan Sebagai Moderasi". Jurnal Ilmiah WIDYA, Vol. 4, No. 2, hlm: 302-308

Makhaiel, N. K. B. 2016. "The Effect of PoliticalEconomic Reform on the Financial Reporting in Egypt". Journal of Financial Reporting and Accounting, Vol. 16, No., hlm: 1-31.

Mardiasmo. 2003. Perwujudan Transparansi dan Akuntabilitas Publik Melalui Akuntansi Sektor Publik: Suatu Sarana Good Governance. Yogyakarta: Universitas Gadjah Mada.

Mawuntu, N. S., H. Manossoh, and D. Afandi. 2020. "Pengaruh Kepatuhan dan Pengawasan Terhadap Kualitas Laporan Keuangan Pemerintah Daerah (Studi Empiris Pada Pemerintah Kabupaten Minahasa Utara)". Going Concern: Jurnal RIset Akuntansi, Vol. 15, No. 2, hlm: 260-268.

Muraina, S. A., and K. I. Dandago. 2019. "Effects of implementation of International Public Sector Accounting Standards on Nigeria's Financial Reporting Quality". International Journal of Public Sector Management, Vol. 33, No. 2/3, hlm: 323-338.

Nkundabanyanga, S. K., V. Tauringana, W. Baluywa, and S. N. Emitu. 2013. "The Association Between Accounting Standards, Legal Framework, and The Quality of Financial Reporting by a Government Ministry in 
Uganda". Journal of Accounting in Emerging Economies, Vol. 3, No. 1, hlm: 65-81.

Putri, N. R., and Agustiawan. 2020. "Faktor-Faktor yang Mempengaruhi Kualitas Laporan Keuangan Pemerintah Daerah (Studi Pada OPD Kabupaten Kampar)". Muhammadiyah Riau Accounting and Business Journal, Vol. 1, No. 2, hlm: 100-109.

Ryan, C., and J. Mack. 2006. "Reflections on the Theoretical Underpinning of General Purpose Financial Reports of Australian Government Departments". Accounting Auditing \& Accountability Journal, Vol. 19, No. 4, hlm: 592-612.

Steccoloni, I. 2004. "Is the Annual Report an Accountability Medium? An Empirical Investigation into Italian Local Governments". Financial Accountability \& Management, Vol. 20, No. 3, hlm: 327-350.

Triono, B. S., and S. N. Dewi. 2020. "Pengaruh Sistem Pengendalian Intern Terhadap Kualitas Laporan Keuangan Pemerintah Daerah". Jurnal Akuntansi dan Pajak, Vol. 21, No. 1, hlm: 213-220.

Yadiati, W., and A. Mubarok. 2017. Kualitas Pelaporan Keuangan. Jakarta: Kencana PrenadaMedia Group.

Yenni, E., M. Irman, and Fadrul. 2020. "Pengaruh Pemahaman Akuntansi dan Penerapan Sistem Informasi Keuangan Daerah Terhadap Kualitas Laporan Keuangan Pemerintah Daerah dengan Kompetensi Sumber Daya Manusia Sebagai Variabel Moderasi (Studi Empiris Pada Pemerintahan Kota Pekanbaru)". Research In Accounting Journal, Vol. 1, No. 1, hlm: 6488. 